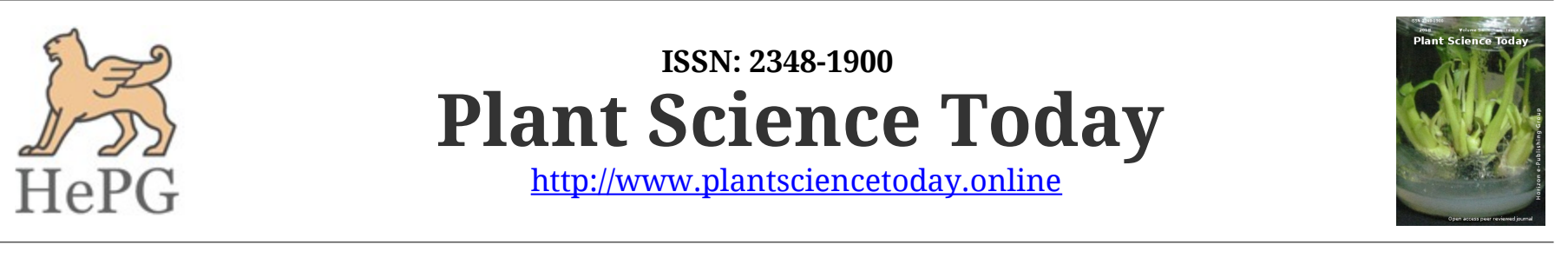

OPEN ACCESS

Research Communication

\title{
Karyotype analysis of Solanum torvum Sw. - an ethnobotanical Solanaceous species of Tripura, North East India
}

\author{
H R Singha*, B D Chowdhury, S Sinha, R K Sinha \\ Cytogenetics and Plant Biotechnology Laboratory, Department of Botany, Tripura University (A Central University), Suryamaninagar, \\ Tripura 799022, India
}

\section{Article history}

Received: 06 September 2018

Accepted: 14 October 2018

Published: 12 November 2018

\section{Editor}

Dr Nishikant Wase, University of Nebraska Lincoln, USA

\section{Publisher}

Horizon e-Publishing Group

\author{
*Correspondence \\ H Reshmi Singha \\ 区reshmisingha90@gmail.com
}

\begin{abstract}
Solanum torvum Sw. is a wild Solanaceous plant species, commonly used by the indigenous people of Tripura. Cytological study of the species was carried out to determine the somatic chromosome number and to construct the karyotype formula. The detailed karyomorphological analysis revealed $2 n=24$ somatic chromosomes having haploid number $\mathrm{n}=12$. The size of chromosomal complement was found to range from $2.14 \pm 0.21$ to $4.02 \pm 0.26 \mu \mathrm{m}$ with a pair of chromosomes bearing secondary constrictions. Strictly median primary constriction was recorded in two pairs of chromosomes. In general, karyotype formula was found to be $\mathrm{A}_{2} \mathrm{~B}_{4} \mathrm{C}_{18}$. The detailed karyotype analysis revealed that chromosomes are generally small in size and fall under the Stebbins category of " $2 \mathrm{~A}$ " indicating symmetrical nature of the karyotype. The present study could be utilised in understanding the cytogenetic nature of the species and for future crop improvement programme.
\end{abstract}

\section{Keywords}

Solanum torvum; ethnobotany; chromosome number; karyomorphology

\section{Citation}

Singha H R, Chowdhury B D, Sinha S, Sinha R K. Karyotype analysis of Solanum torvum Sw. - an ethnobotanical Solanaceous species of Tripura, North East India. Plant Science Today 2018;5(4):191-195. https://dx.doi.org/10.14719/pst.2018.5.4.421

Copyright: (C) Singha et al. (2018). This is an open-access article distributed under the terms of the Creative Commons Attribution License, which permits unrestricted use, distribution, and reproduction in any medium, provided the original author and source are credited (https://creativecommons.org/licenses/by/4.0/).

Indexing: Plant Science Today is covered by Scopus, CAS, AGRIS, CABI, Google Scholar, etc. Full list at http://www.plantsciencetoday.online

\section{Introduction}

Solanum torvum Sw. belonging to the family Solanaceae, is one of the important ethnobotanical wild species of Tripura, North East India. The $S$. torvum is mostly distributed in road sides and waste places. Fruits of the species are used as vegetables by the local people and infrequently available in some local markets of Tripura $(1,2,3$, 4) since there is as such no organised cultivation.
Fruits are also used in traditional medicine to cure cough, bronchial asthma, liver and spleen enlargement $(5,6,7,8,9)$. The species also has pharmaceutical importance due to the presence of a good source of secondary metabolites such as alkaloids, flavonoids, saponins, tannins and glycosides in their wild fruits $(10,11)$.

Karyotype studies have been extensively carried out in plant phylogenetics and diversity 


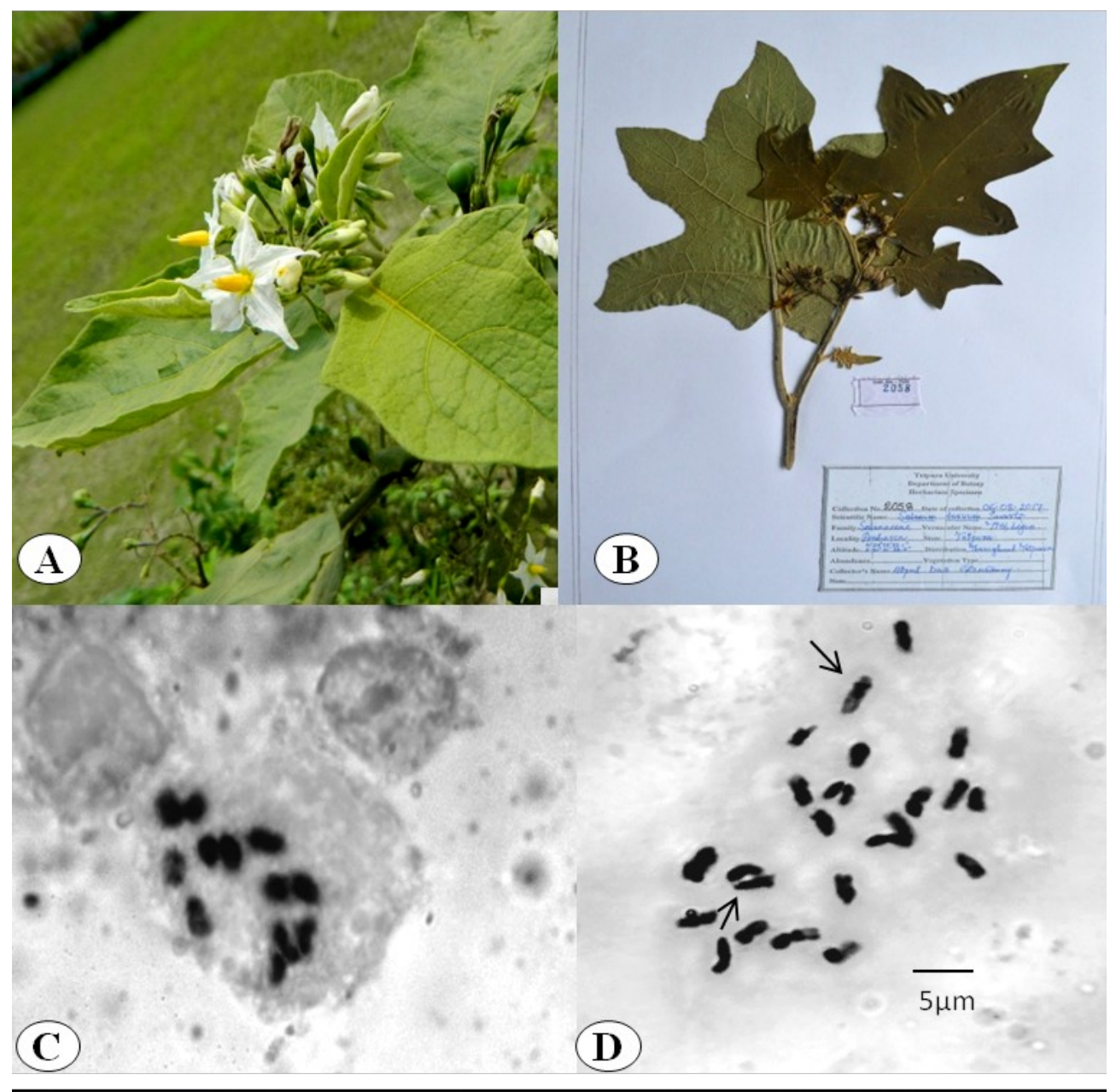

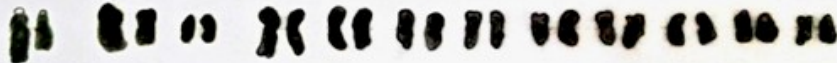

\author{
(E) L. A $_{-} \mathrm{IL} \longrightarrow \mathrm{B} \longrightarrow$
}

Fig. 1: A. Flowering twig of the Soanum torvum Sw.; B. Herbarium of the same; C. Meiotic metaphase plate showing $\mathrm{n}=12$ bivalents; D. Mitotic metaphase plate showing $2 \mathrm{n}=24$ chromosomes; E. Karyogram showing different chromosome types of S. torvum (arrow indicating secondary constriction bearing chromosomes)

research. In this era of modern molecular techniques, cytology is still a valuable method for taxonomy and diversity studies (12). The information on the karyotypic features of the species i.e. the chromosome number, size, morphology and behaviour of the chromosomes during meiosis and mitosis are important for comparative assessment of the genomic compatibility between species/varieties for future crop improvement programmes (13). Karyotype analyses have been regarded as an important method for exploring the genomic information of organisms, endowed with the length of chromosome, arm ratio, relative length of chromosome and position of centromeres (14). Chromosomal study and karyotype analysis have also been regarded as an important step for genetic improvement programmes and conservation of wild gene pool (15).

In spite of some ethnobotanical (16), reproductive biology (17) and comparative cytological analyses (18) there is as such no detailed record on karyomorphological characteristics of the $S$. torvum growing wild in this region. Therefore the present study has been carried out to explore the karyomorphological details of $S$. torvum - a useful Solanaceous wild species of Tripura, North East India.

\section{Materials and Methods}

Plant material was collected from the wild population of Ambasa, Dhalai Tripura (Fig. 1A) with a geographical coordinate latitude $\mathrm{N}$ $23^{\circ} 55^{\prime} 52.1^{\prime \prime}$ and longitude E $091^{\circ} 51^{\prime} 38.9^{\prime \prime}$ having 91 $\mathrm{m}$ elevation. After the collection, the species was identified by detailed morphometric workout and finally compared with the species characters of the sample through consultation with "Flora of Tripura" (19) and herbarium was prepared (Fig. 1B) along with definite collection number TUH2058 and deposited at the herbarium centre of Department of Botany, Tripura University. 
Table 1: Karyomorphological characteristics of Solanum torvum Sw.

\begin{tabular}{|c|c|c|c|c|c|c|}
\hline $\begin{array}{c}\text { No of } \\
\text { chromosome } \\
\text { complements in } \\
\text { pairs }\end{array}$ & $\begin{array}{l}\text { *Average total } \\
\text { length of } \\
\text { chromosomes } \\
(\mu \mathrm{m})\end{array}$ & $\begin{array}{c}\text { *Average } \\
\text { length of } \\
\text { short arm } \\
(\mu \mathrm{m})\end{array}$ & RLC & Average F\% & $\begin{array}{l}\text { Nature of primary } \\
\text { constriction }\end{array}$ & $\begin{array}{c}\text { Chromosome } \\
\text { type }\end{array}$ \\
\hline \multirow{2}{*}{1} & \multirow{2}{*}{$4.02 \pm 0.26$} & $0.61 \pm 0.13$ & \multirow{2}{*}{10.98} & $15.20 \pm 3.28$ & st & \multirow{2}{*}{ A } \\
\hline & & $1.10 \pm 0.09$ & & $28.06 \pm 1.40$ & $\mathrm{sm}$ & \\
\hline 2 & $3.14 \pm 0.08$ & $1.57 \pm 0.04$ & 8.58 & $50.00 \pm 0.00$ & M & B \\
\hline 3 & $2.14 \pm 0.21$ & $1.07 \pm 0.10$ & 5.84 & $50.00 \pm 0.00$ & $\mathrm{M}$ & B \\
\hline 4 & $3.90 \pm 0.40$ & $1.55 \pm 0.03$ & 10.65 & $40.18 \pm 4.32$ & $\mathrm{~m}$ & C \\
\hline 5 & $3.41 \pm 0.21$ & $1.38 \pm 0.21$ & 9.31 & $40.48 \pm 5.34$ & $\mathrm{~m}$ & $\mathrm{C}$ \\
\hline 6 & $3.20 \pm 0.27$ & $1.45 \pm 0.13$ & 8.74 & $45.28 \pm 1.35$ & $\mathrm{~m}$ & $\mathrm{C}$ \\
\hline 7 & $3.08 \pm 0.00$ & $1.47 \pm 0.14$ & 8.41 & $47.99 \pm 4.49$ & $\mathrm{~m}$ & $\mathrm{C}$ \\
\hline 8 & $2.95 \pm 0.12$ & $1.32 \pm 0.21$ & 8.06 & $47.72 \pm 5.46$ & $\mathrm{~m}$ & C \\
\hline 9 & $2.95 \pm 0.33$ & $1.21 \pm 0.19$ & 8.06 & $40.96 \pm 3.14$ & $\mathrm{~m}$ & C \\
\hline 10 & $2.69 \pm 0.23$ & $1.05 \pm 0.05$ & 7.35 & $39.49 \pm 4.06$ & $\mathrm{~m}$ & $\mathrm{C}$ \\
\hline 11 & $2.58 \pm 0.21$ & $1.00 \pm 0.21$ & 7.05 & $39.13 \pm 5.30$ & $\mathrm{~m}$ & $\mathrm{C}$ \\
\hline 12 & $2.55 \pm 0.22$ & $1.01 \pm 0.20$ & 6.96 & $39.37 \pm 5.94$ & $\mathrm{~m}$ & C \\
\hline
\end{tabular}

Note: *Average of five metaphase plates. RLC - Relative length of chromosome. F\% - Forma percentage.

Table 2: Summarized karyomorphological details and karyotype category of S. torvum Sw.

\begin{tabular}{ccccc}
\hline $\begin{array}{c}\text { Ratio of Longest and } \\
\text { shortest chromosome } \\
\text { length }(\mu \mathrm{m})\end{array}$ & $\begin{array}{c}\text { Number of } \\
\text { chromosomes with arm } \\
\text { ratio }<2: 1\end{array}$ & $\begin{array}{c}\text { TCL in haploid set } \\
(\mu \mathrm{m})\end{array}$ & TF\% & $\begin{array}{c}\text { Stebbins karyotype } \\
\text { category }\end{array}$ \\
\hline 1.88 & 22 & 36.61 & 41.46 & $2 \mathrm{~A}$ \\
\hline
\end{tabular}

Note: TCL -Total chromosome length. TF\% - Total forma percentage.

Meiotic chromosome study of $S$. torvum was carried out by $2 \%$ aceto-carmine staining technique using prefixed (overnight fixed) flower buds ( $0.5 \mathrm{~mm}$ in size) between 9 a.m. to 10 a.m. in glacial acetic acid and alcohol mixture in 1:3 ratio. For mitotic chromosome study, root tip meristem was generated by keeping the seedling in normal tap water using conical flask and grown in normal room temperature. After 5-10 days, fresh root tips were emerges out from the seedling and root tips measuring 1-1.5 cm were collected between 10 a.m. to 11 a.m. and pretreated with saturated para-Dicholorobenzene (PDB) and 8Hydroxyquinoline in 1:1 ratio for $4.30 \mathrm{~h}$. Then the pretreated root tips were fixed in 1:3 acetic acid and ethyl alcohol mixture for overnight. Next day, root tips were treated with $45 \%$ acetic acid for 30 min and subsequently root tips were hydrolysed in $1 \mathrm{~N} \mathrm{HCl}$ for $20 \mathrm{~min}$. After proper softening, staining of the root tip cells was done with $2 \%$ aceto-orcein (20). After $2 \mathrm{~h}$ of staining, root tips were squashed in $45 \%$ acetic acid and observed under compound microscope. At least 50 metaphase plates were observed and five well spread metaphase plates were drawn using camera lucida under oil immersion objective and photographs were taken using Sony Cyber shot DSC-W320 camera. Measurements of different chromosomal complements like size of short arm, long arm, forma percentage, relative length of chromosomes (RLC), arm ratio, total chromosome length in haploid set (TCL), etc were done from camera lucida drawn pictures and presented in a tabular form.

\section{Results and Discussion}

Cytological analysis of $S$. torvum clearly revealed $2 n=24$ chromosomes (Fig. 1D). Moreover, the presence of 12 regular bivalents during meiosis indicates that its haploid chromosome number is $\mathrm{n}=12$ (Fig. 1C). This observation is in accordance with the previous reports (21). The different karyotypic parameters such as total length of chromosomes, length of short arms, total haploid chromosome length, total forma percentage (TF\%) and position of centromere were determined and summarized in tabular form (Table 1 and 2). The average length of the largest and smallest chromosomes were found to be $4.02 \pm 0.26 \mu \mathrm{m}$ and $2.14 \pm 0.21 \mu \mathrm{m}$ respectively with a total forma percentage of $41.46 \%$. The range of relative length of chromosome (RLC) varied from $6.96 \mu \mathrm{m}$ to 10.98 $\mu \mathrm{m}$ and the total length of the haploid chromosomes was found to be $36.61 \mu \mathrm{m}$. Although there is no difference in somatic chromosome number with the earlier report but the critical examination revealed a characteristic difference in different karyotypic features like size of the chromosome, which ranges from $0.60 \mu \mathrm{m}$ to 3.10 $\mu \mathrm{m}$ with a 45.9 total forma percentage (TF\%). The relative length of chromosome varies from 1.37 
$\mu \mathrm{m}$ to $7.08 \mu \mathrm{m}$ (22). Whereas, according to Oyelana (23), the size of the chromosome of $S$. torvum ranges from $0.94 \mu \mathrm{m}$ to $1.29 \mu \mathrm{m}$. Such kind of variation in different karyomorphological accounts of the species at different locations was also reported by Krishnappa and Chennaveeraiah (24). The species $S$. torvum was characterized with one pair of secondary constriction in the largest chromosome pair and the secondary constriction is associated with the short arm of the chromosome. On the basis of the size of chromosomes and nature of constrictions the chromosomes are classified into following categories (25).

Type A: Chromosome bearing a secondary constriction with an average size 4.02 $\pm 0.26 \mu \mathrm{m}$ having one sub-telomeric constriction and another sub-metacentric constriction.

Type B: Chromosomes with an average size range $2.14 \pm 0.21 \mu \mathrm{m}$ to $3.14 \pm 0.08 \mu \mathrm{m}$ having typical metacentric (M) constrictions.

Type C: Chromosomes with an average size range $2.55 \pm 0.21 \mu \mathrm{m}$ to $3.90 \pm 0.40 \mu \mathrm{m}$ having nearly metacentric (m) primary constrictions.

The present karyotype study of the species reveals two pair of strictly median chromosomes (M), 9 pair of nearly median chromosomes (m) and one pair of sub-median chromosome (sm) having sub-telomeric (st) secondary constriction. Thus the karyotype formula of the $S$. torvum is $\mathrm{A}_{2} \mathrm{~B}_{4} \mathrm{C}_{18}$ (Fig. $1 \mathrm{E})$. In the present study, out of 24 somatic chromosomes, 22 are found to have arm ratio (L/S) less than $2: 1(<2: 1)$. On the other hand the ratio of longest to shortest chromosome was $1.88 \mu \mathrm{m}$, i.e. less than 2:1. Thus according to the Stebbins (26) degree of symmetry karyotype of the $S$. torvum belongs to the 2A category suggesting its symmetrical nature.

\section{Acknowledgement}

Authors are highly thankful to the University Grants Commission (UGC), New Delhi, for providing BSR fellowship (No. F. TU/FIN(233)/ (P)/12) to carry out the present research work.

\section{Conflict of interest}

The authors have declared that there is no conflict of interest.

\section{Authors' contribution}

SHR carried out the whole experimental work, data analysis and manuscript preparation, CBD collected the plant material and helped in identification of species, SS and SRK supervised and structured the manuscript for final submission.

\section{References}

1. Agarwal AD, Bajpei PS, Patil AA, Bavaskar SR. Solanum, torvum Sw. - A phytopharmocological review. Scholars research library. Der Pharmaica letter 2010; 2 (4): 403-407.

2. Choudhury R, Datta Choudhury M, De B, Paul SB. Importance of certain tribal edipble plants of Tripura. Indian journal of traditional knowledge 2010; 9 (2): 300-302.

3. Deb D, Sarkar A, DebBarma B, Datta BK, Majumdar K. Wild Edible Plants and Their Utilization in Traditional Recipes of Tripura, Northeast India. Advances in Biological Research 2013; 7 (5): 203-211. https://doi.org/10.5829/idosi.abr.2013.7.5.11895

4. Singha HR, Sinha S, Sinha RK. Clonal propagation and karyomorphological study of Solanum torvum Sw.-an ethnobotanical species of Tripura, India. Plant Tissue Cult. And Biotech. 2018; 28(1):69-76. https://doi.org/10.3329/ptcb.v28i1.37199

5. Kala CP. Ethnomedicinal botany of the Apatani in the Eastern Himalayan region. Indian, J Ethno and Ethnomed 2005; 1:1-8. https://doi.org/10.1186/17464269-1-1

6. Yuanyuan LU, Jianguang L, Xuefeng H, Lingyi K. Four steroidal glycosides from Solanum torvum and their cytotoxic activities. Steroids 2009; 74:95-101. https://doi.org/10.1016/j.steroids.2008.09.011

7. Jaiswal BS. Solanum torvum: a review of its traditional uses, phytochemistry and pharmacology. Int J Pharm Bio Sci 2012; 3(4): $104-111$.

8. Kannan M, Dheeba B, Gurudevi S, Ranjit Singh AJA. Phytochemical, antibacterial and antioxidant studies on medicinal plant Solanum torvum. Journal of Pharmacy Research 2012; 5 (5): 2418-2421.

9. Sundari SG, Rekha S, Paravathi A. phytochemical evaluation of three species of Solanum L. Int. J. Res. Ayurveda Pharm. 2013; 4(3): 420-425. https://doi.org/10.7897/2277-4343.04323

10. Chah KF, Muko KN and Oboegbulem SI. Antimicrobial activity of methanolic extract of Solanum torvum fruit. $\begin{array}{llll}\text { Fitoterapia } & \text { 2000; } & \text { 71: } & \text { 187-189. }\end{array}$ https://doi.org/10.1016/S0367-326X(99)00139-2

11. Lakshmi DNP and Ponmurugan N. In vitro Interactions Between Solanum torvum Extracts and Microbes. Academic Journal of Plant Sciences 2013; 6 (1): 47-51. https://doi.org/10.5829/idosi.ajps.2013.6.1.325

12. Mukherjee A, Roy SC. Karyotype analysis $\mathrm{f}$ five species of Allium. Indian Journal of Fundamental and Applied life Sciences 2012; 2(2): 374-383.

13. Vandana, Chaudhary BR. Intervarietal karyotypic variation in Vicia faba L. Caryologia: Iternational journal of cytology, cytosystematicss and cytogenetics 2013; 66(1): 6-11 https://doi.org/10.1080/00087114.2013.780435

14. Chaudhari AK, Chaudhary BR. Intraspecific karyotypic variability among accessions of Psoralea corylifolia L.- A medicinally important plant. Vegetos 2013; 26(1): 19-26. https://doi.org/10.5958/j.2229$\underline{4473.26 .1 .003}$

15. Thelagathoti DC, Chapara M. A Preliminary Study on Karyotype Analysis of Normal vs. Diseased Nemipterus japonicus off Visakhapatnam, India. International Journal of Animal Biology 2015; 1(3): 74-77. 
16. Deb D, Sarkar A, DebBarma B, Datta BK, Majumdar K. Wild Edible Plants and Their Utilization in Traditional Recipes of Tripura, Northeast India. Advances in Biological Research 2013; 7 (5): 203-211. https://doi.org/10.5829/idosi.abr.2013.7.5.11895

17. Saha M, Datta BK. Observations on the reproductive biology of Solanum torvum Swartz (Solanaceae): an important medicinal plant in North-east India. The International Journal of Plant Reproductive Biology 2017; 9(1): 25-27. https://doi.org/10.14787/ijprb.2017 9.1.25-27

18. Singha HR, Sinha S, Sinha RK. Comparative cytological and fruit biochemical studies in two populations of Solanum torvum Sw. - an ethnobotanical species of North East India. Taiwania 2018; 63(2):101-105.

19. Deb DB. The flora of Tripura. Today and tomorrow printers and publishers.Vol-II. 1983.

20. Sharma AK, Sharma A. Chromosome technique Theory and Practice Third edition. Butterworths Ltd. London 1980.
21. Obute GC, Ndukwu BC, Okoli B E. Cytogenetic studies on some Nigerian species of Solanum L. (Solanaceae). African Journal of Biotechnology 2006; 9: 689-692.

22. Das AK, Borah SP. Assessment of genetic diversity among some important wild species of non-tuberous Solanum using RAPD and ISSR markers. International Journal of Bioscience 2015; 6(3): 1029-1042.

23. Oyelana AO. Karyotypic analysis and meiotic chromosomes in eight taxa of Solanum species (Solanaceae). Acta SATECH 2005; 2(1): 24-29.

24. Krisnappa DG, Chennaveeraiah MS. Karyomorphological studies in spinaceous species of Solanum. Cytology 1976; 42(1): 25-28.

25. Levan AK, Fredga K, Sandberg A. Nomenclature for centromeric position on Chronosomes. Hereditas 1964; 52: 201-220. $\quad$ https://doi.org/10.1111/j.16015223.1964.tb01953.x

26. Stebbins GL. Chromosomal evolution in higher plant. Edward Arnold., London 1971. 